\title{
MEDICINE
}

\section{DYNAMICS OF CELLULAR IMMUNE RESPONSE IN SHIGELLOSIS IN CHILDREN INFECTED WITH CYTOMEGALOVIRUS}

\author{
Graduate student, Bukiy S. M., \\ Professor, Olkhovska O. M.,
}

Ukraine, Kharkiv, Kharkiv National Medical University

DOI: https://doi.org/10.31435/rsglobal_ws/31032020/6973

\section{ARTICLE INFO}

Received: 10 January 2020

Accepted: 15 March 2020

Published: 31 March 2020

\section{KEYWORDS}

cellular immunity,

children,

shigellosis,

cytomegalovirus infection.

\begin{abstract}
The analysis of the cellular immune response indicators in shigellosis in 90 children aged four to ten years infected with cytomegolovirus. It was found that in the acute period of the disease in children with mixed infection, the content of CD3 +, CD4 + and CD8 + cells of peripheral blood decreases, and by the period of early reconvalescence, the full recovery of cellular immunity indicators in these children does not occur. The revealed features of cellular immunity in shigellosis in children infected with CMV may be the cause of an unfavorable course of the disease and require further research.
\end{abstract}

Citation: Bukiy S. M., Olkhovska O. M. (2020) Dynamics of Cellular Immune Response in Shigellosis in Children Infected with Cytomegalovirus. World Science. 3(55), Vol.2. doi: 10.31435/rsglobal_ws/31032020/6973

Copyright: (C) 2020 Bukiy S. M., Olkhovska O. M. This is an open-access article distributed under the terms of the Creative Commons Attribution License (CC BY). The use, distribution or reproduction in other forums is permitted, provided the original author(s) or licensor are credited and that the original publication in this journal is cited, in accordance with accepted academic practice. No use, distribution or reproduction is permitted which does not comply with these terms.

Despite the achievements of the medical industry in reducing the incidence of intestinal infections in Ukraine [1, 2], shigellosis remains one of the most common bacterial infections, especially among children, sometimes causing outbreaks of this disease [3]. Based on the pathogenesis of shigellosis, both extracellular and intracellular location of the pathogen is possible. Bacteria and lipopolysaccharides of their cell membranes are one of the starting factors for the development of the inflammatory process, the course of which largely depends on the body's protective reaction - both specific and non-specific links. In the process of sanogenesis, one of the leading places is occupied by the activation of cellular and humoral links of the immune response $[4,5]$, which plays a leading role in recognizing an indefinitely large number of various antigen molecules and implementing their subsequent destruction and elimination from the body [6].

The effective functioning of the immune system is due to the balance of regulatory cytokines, which are responsible for the balance of Th1 and Th2 links. The study of lymphocyte subpopulations allows us to characterize the state of the cellular link of the immune response, which occurs with the help of antigen-specific identification receptors of lymphocytes [7]. CD cells become functionally active as a result of interaction of TCR with the antigen complex and the MNS class I molecule on the surface of the infected target cell [8].

Many studies have been conducted on the state of the immune response in shigellosis. Thus, the immunosuppressive activity of Shigella has been proven in experimental infection of both animals and humans $[9,10]$. Other scientists claim that the inhibition of CD8 + cytotoxic response is not associated with Shigella secretion products [11, 12]. The obtained research results are often contradictory and require further study. 
The state and functional activity of the immune system of a child's body can be influenced by many different factors, including infection of children with herpes viruses, primarily cytomegalovirus (CMV). Infection occurs mainly during the first three years of a child's life and may be accompanied by virus damage to the lymphatic systems and immune cells [13]. Long-term persistence of herpes viruses in the human body can lead to violations of the normal functioning of the immune system, which can affect the course of the underlying disease, including shigellosis. However, in the sources available to us, we have not found studies on the state of the immune response in shigellosis in children infected with CMV.

The aim of this research is to study the features of the immune response in shigellosis of children infected with CMV.

Research materials and methods. The study was conducted on the basis of the Regional children's infectious diseases clinical hospital in Kharkiv. We examined 90 children aged four to ten years with shigellosis, who were divided into two groups, comparable in age and gender $(\mathrm{p}>0.05)$. The first group consisted of 48 children with shigellosis without co-infection with viruses (monoinfection), whose average age was $8.21 \pm 1.74$ years. The second group included 42 patients with shigellosis on the background of persistent inactive CMV infection (the average age of children was $7.87 \pm 2.05$ years). All children were treated in accordance with approved current clinical protocols. The control group consisted of 20 practically healthy children (average age $7.21 \pm 1.22$ years).

The diagnosis of shigellosis was established in accordance with ICD-10, taking into account clinical and anamnestic data, bacteriological, virological and serological studies. All children were examined for CMV by ELISA (determination of IgM and IgG antibodies to CMV in blood serum). The presence of CMV in saliva and blood was also determined by PCR. The condition for exclusion from the cohort of the study was the detection of markers of other herpes viruses in patients (EpsteinBarr virus, herpes virus type 6), the presence of concomitant pathology, and the state of immunodeficiency. Along with conventional studies, the levels of populations and subpopulations of peripheral blood lymphocytes were determined by indirect immunofluorescence using monoclonal antibodies to the surface antigens of CD3+, CD4+, CD8+, and CD19+-lymphocytes. Static processing of the obtained results was performed using computer programs Excel and Statistica 6.0.

Results of the study and their discussion. In the dynamics of shigellosis (acute period is 1-2 day of the disease and the period of convalescence -7-10 day) was determined as the cell component of the immune response in children with mono-infection and against the infections of patients with CMV. Indicators of the main subpopulations of lymphocytes in children of observation groups in different periods of shigellosis are shown in the table.

Table 1. Indicators of cellular immunity of children with shigellosis, $(\mathrm{M} \pm \mathrm{m})$

\begin{tabular}{|c|c|c|c|c|}
\hline Indicator & Period & First group & Second group & Control \\
\hline \multirow{2}{*}{$\mathrm{CD} 3^{+}, \%$} & acute & $55,63 \pm 1,05^{1,2}$ & $52,24 \pm 0,83^{1}$ & \multirow{2}{*}{$61,42 \pm 1,23$} \\
\hline & reconvalescences & $60,58 \pm 0,57^{2}$ & $56,11 \pm 0,87^{1}$ & \\
\hline \multirow{2}{*}{$\mathrm{CD} 4^{+}, \%$} & acute & $31,46 \pm 1,12^{1,2}$ & $26,84 \pm 1,06^{1}$ & \multirow{2}{*}{$37,31 \pm 0,72$} \\
\hline & reconvalescences & $36,95 \pm 0,48^{2}$ & $33,53 \pm 1,09^{1}$ & \\
\hline \multirow{2}{*}{$\mathrm{CD} 8^{+}, \%$} & acute & $24,64 \pm 0,97^{2}$ & $18,81 \pm 0,96^{1}$ & \multirow{2}{*}{$26,83 \pm 0,54$} \\
\hline & reconvalescences & $26,72 \pm 0,64^{2}$ & $23,48 \pm 0,41^{1}$ & \\
\hline \multirow{2}{*}{$\mathrm{CD} 16^{+}, \%$} & acute & $25,52 \pm 0,57^{1,2}$ & $23,25 \pm 0,55^{1}$ & \multirow{2}{*}{$16,38 \pm 0,72$} \\
\hline & reconvalescences & $20,07 \pm 1,53^{1}$ & $19,15 \pm 0,68^{1}$ & \\
\hline \multirow{2}{*}{$\mathrm{CD} 22^{+}, \%$} & acute & $25,18 \pm 0,64^{2}$ & $22,43 \pm 1,08$ & \multirow{2}{*}{$23,54 \pm 0,62$} \\
\hline & reconvalescences & $26,49 \pm 1,05^{1,2}$ & $23,57 \pm 0,39$ & \\
\hline
\end{tabular}

Notes: 1 - probability of a sign to control;

2 - probability of a trait between observation groups.

In the debut of shigellosis in patients of the observation groups, a decrease in the content of CD3+ and CD4+ blood lymphocytes was determined, which indicated the suppression of the cellular link of the immune response, while the most pronounced changes were observed in patients of the second group $(\mathrm{p}<0.001)$. In children infected with CMV, the concentration of CD8 + cells was also significantly low $(\mathrm{t}=7.58 ; \mathrm{p}<0.001)$, while in patients with monoinfection, CD8 + levels did not differ significantly from the control data $(\mathrm{t}=1.97 ; \mathrm{p}<0.05)$. Our results do not contradict the data of other studies, which indicated 
a transient inhibition of cellular immunity in patients infected with CMV, with various pathologies $[14,15]$. But these studies were conducted mainly in adults with respiratory tract inflammation, joint diseases, and others. There are studies of cellular immunity in children with shigellosis, in which there is a violation of the regulation of the immune response by cell type [16]. However, these studies were conducted in young children without specifying the etiological factor of herpes virus infection.

We found a significant increase in the content of CD $16+$ lymphocytes, the most pronounced in patients with monoinfection, which differed not only from the control values $(t=9.95 ; \mathrm{p}<0.001)$, but also from the indicators of children of the second group $(t=2,87 ; p<0.05)$. The latter fact, in our opinion, indicates a significant activation of natural killers, which contribute to the sanation of the body in bacterial infections [16]. Unfortunately, when children are infected with CMV, these processes can be disrupted. The study of the state of the cellular immune response in intestinal infections is relevant, given the revealed influence of immunosuppression on the intestinal microbiocenosis, the risk of developing bloodstream infections [17].

In patients with shigellosis, the dynamics of the disease increases the level of CD $22+$ lymphocytes, which indirectly reflects the activation of the humoral link of the immune response and contributes to recovery. Children of the first group showed significantly higher CD $22+$ cell counts compared to patients of the second group both in the acute period of the disease $(t=2.19 ; \mathrm{p}<0.05)$ and at the stage of early reconvalescence $(\mathrm{t}=2.61 ; \mathrm{p}<0.05)$. Insignificant changes in the concentration of CD $22+$ lymphocytes in patients of the second group, whose indicators, although increased in the dynamics of the disease, did not differ significantly compared to the control in the acute period $(\mathrm{t}=0.89 ; \mathrm{p}<0.05)$, and in the period of reconvalescence $(\mathrm{t}=0.04 ; \mathrm{p}<0.05)$, drew attention to themselves. The effect of CMV on the cellular link of the immune response was determined by other authors. Our data do not match the results of L. V. Moroz et al. (2018), who found inhibition of the humoral link of the immune response in patients infected with CMV, but the study was conducted in adults with extra-hospital pneumonia without taking into account its etiological factor. [18]. In our study, we did not find a significant decrease in the content of CD $22+$ lymphocytes, which can be explained by the stress in the work of humoral immunity against the background of a transient decrease in the concentration of cellular immune response indicators. Such changes are adaptive, but can lead to rapid disruption of adaptation responses.

In the period of early reconvalescence, we revealed significant dynamics of $\mathrm{CD} 3+, \mathrm{CD} 4+$ and $\mathrm{CD} 16+$ lymphocyte indices $(\mathrm{p}<0.01)$ in patients of the first group: the indicators of CD3 +, $\mathrm{CD} 4+$ and CD8 + in patients of the first group approached the control data $(\mathrm{p}<0.05)$, which indicated the restoration of cellular immunity. We did not find significant differences in the dynamics of other indicators in patients of the first group.

In patients of the second group, significant changes in all indicators in the dynamics of shigellosis were registered. The most pronounced changes were in relation to $\mathrm{CD} 16+(\mathrm{t}=4.68$, $\mathrm{p}<0.001), \mathrm{CD} 8+(\mathrm{t}=4.47, \mathrm{p}<0.001)$ and CD4 $+(\mathrm{t}=4.40, \mathrm{p}<0.001)$. At the same time, in the period of reconvalescence in patients of the second group, the indicators of CD3 +, CD4 + and CD8 + remained significantly lower than those of the control group $(\mathrm{p}<0,01)$, which indicated the preservation of transient immunodeficiency. Despite the decrease in CD16 + indicators in patients of both groups in the dynamics of shigellosis, these indicators still remained elevated compared to the control group $(\mathrm{p}<0,05)$.

The revealed violations of the regulation of the immune response by cell type in children with shigellosis against the background of CMV infection is one of the factors that can contribute to the wave-like, unfavorable course of the disease, the layering of secondary infection.

Conclusions.

1. CMV infection in children with shigellosis significantly affects the cellular level of the immune response.

2. The acute course of shigellosis in children is accompanied by a decrease in the content of $\mathrm{CD} 3+, \mathrm{CD} 4+$ and $\mathrm{CD} 8+$ cells of the peripheral blood, the most pronounced changes occur in the conditions of infection of CMV patients.

3. During the period of early reconvalescence, CMV infected children do not fully recover their cellular immunity indicators.

4. The revealed disorders in the immune system of shigellosis patients and CMV-infected children may be the cause of an unfavorable course of the disease and require further research. 


\section{REFERENCES}

1. Денисова М.Ф., Музыка Н.Н., Чернега Н.В., Задорожная Т.Д., Арчакова Т.Н., // Особенности течения язвенного колита у детей на современном этапе // Здоровье ребенка. - 2017. - № 1. - С. 228-231.

2. Матейко Г. Б., Осипчук М.М., Цимбаліста О.Л., Пилипюк Г.М // Практические рекомендации Всемирной гастроэнтерологической организации. Острая диарея. [Електронний ресурс] - Режим доступа: http://www.omge.org/ globalguidelines/guide01/guideline1.htm.

3. Малыш Н., Кузнецова А.Л. Современные аспекты эпидемиологии шигеллезов в северо-восточном регионе Украины. Украинский медицинский журнал. № 5 (97). - IX / Х. - 2013.

4. Савченко А.А., Мартынова Г.П. Особенности состояния иммунной системы и функциональная активность лейкоцитов крови при острых кишечных инфекциях у детей /Сибирский медицинский журнал, 2015г. - 178c.

5. Ризопулу А.П. Взаимодействия патогенных бактерий с врожденными иммунными реакциями хозяина / А.П. Ризопулу, Ф.Ю. Гариб // Инфекция и иммунитет. - 2012. - №3. - С. 581-596.),

6. Турова М.М., Новикова В.О. факторы, влияющие на антифунгальную резистентность у детей с хроническими гастродуоденитами / Проблемы медицинской микологии. - 2016. - № 4. - С. 97-103.

7. Супрун Е.Н. /цитокины и аутоантитела к цитокинам// аллергология и иммунология в педиатрии. 2018. - № 2 - c. 61-65.

8. Queiroz DM. Children's antidiarrheal oral liquid / DM. Queiroz, AM. Rocha, JE. Crabtree // Gut Microbes. - 2014. - V. 4, № 6. - P. 491-495.

9. Dore M. Gastrointestinal symptoms and Helicobacter pylori infection in school-age children residing in Porto Torres Sardinia, Italy / M. Dore, G. Franciulli, P. Tomasi et al. // Helicobacter - 2012. - V. 17, № 5. - P.369-373.

10. Maman Y. Bacteria Modulate the CD8 + T Cell Epitope Repertoire of Host Cytosol-Exposed Proteins to Manipulate the Host Immune Response / Y. Maman, R. Nir -Paz, Y. Louzoun // PLOS Computational Biology. - 2011. - Vol. 7 (10).

11. Anderson M. Shigella Diversity and Changing Landscape: Insights for the Twenty-First Century / M. Anderson, P.J. Sansonetti, B.S. Marteyn // Frontiers in Cellular and Infection Microbiology. - 2016. - Vol.6.45.

12. Tan Xiaoli. Kit and method for detecting HCMV (human cytomegalovirus)./ Tan Xiaoli, Zhang Jiandong, Dou Yaling, Li Zhixin.// Infection disease. - 2014. - V. 171, № 5. - P.1643-1646.

13. Chichirello-Konstantinovich, K., Konstantynovych, T., \& Moroz, L. (2017). Peculiarities of Immune Status among Young Patients with Community-Acquired Pneumonia (CAP) during Cytomegaloviral Persistence (CMVP). European Respiratory Journal, 50 (61), PA987. doi: 10.1183 / 1393003

14. Клинико-иммунологическая характеристика шигеллеза, ассоциированного с герпесвирусными инфекциями, у детей: клиника, диагностика и лечение. Симованьян Э.Н., Денисенко В.Б. Детские инфекции. 2017 T. 16. № 4. С. 29-36.

15. Walter Mark R. Methods and Compositions for Cytomegalovirus IL-10 Protein / Walter Mark R, Barry Peter A // Clinical Infectious Diseases - 2012. - V. 54, № 4. - P.36-43.

16. Микробиота кишечника в пациентов с иммуносупрессией: переоценка взглядов на патогенез инфекций кровотока. Стома И.О. Клиническая Инфектология и Паразитология. 2018. № 2. С. 224-233.

17. Имунореактивнисть больных негоспитальную пневмонию молодого возраста при цитомегаловирусной персистенции. Л.В.Мороз, К. Д. Чичирельо-Константинович, Т.В.Константинович, В. М. Дудник. Запорожский медицинский журнал. - 2018. - Т. 20, № 6 (111). - С. 768-774. DOI: 10.14739 / 2310-1210. 2018.6.146575. 